\title{
STRUCTURAL-GEODYNAMIC CONTROL OF KIMBERLITE PIPES OF THE YAKUT DIAMOND PROVINCE ACCORDING TO THE DATA OF GRAVISTRUCTURAL ANALYSIS
}

\begin{abstract}
S.M. Makeev $\oplus^{凶}$
Siberian Federal University, 79 Svobodny Ave, Krasnoyarsk 660041, Russia

ABSTRACT. The article deals with the fundamental concepts of a new method of interpretation of regional gravimetry (scale 1:1000000) based on the idea of the deformational nature of low-frequency gravity anomalies. The method provided an opportunity to identify the direction of tectonic compression in the Yakut diamond-bearing province, to localize segments and axes of inter-shear compression and extension of different kinematics and on that basis to distinguish the shear interaction zones spatially correlating with the location of kimberlite pipes. Particularly, the whole area is characterized by four transpressive compression directions: a pair of orthogonal (dextral with azimuth $8^{\circ}$ and sinistral with azimuth $98^{\circ}$ ) and a pair of diagonal (dextral with azimuth $38^{\circ}$ and sinistral with azimuth $128^{\circ}$ ). These data correlate to those from the regional tectonophysical studies not only within the compression direction azimuths but also within kinematics of transpressive motions for two main phases in geodynamical evolution of the Yakutsk diamond-bearing province (YDP) - predominantly dextral for the first phase of the northeastern compression and sinistral for second phase of the northwestern compression. The article also shows that the Alakit-Olenek mineragenic zone is an extensive $(\sim 500 \mathrm{~km})$ area of plastic deformation of rocks $\sim 90 \mathrm{~km}$ in width with the right-lateral kinematics of apparent motions of the rocks along its northern and southern boundaries. The southern boundary of the mineragenic zone exhibits the northeaststriking continuity whereas its northern boundary is discontinuous. The boundaries of the Alakit-Olenek mineragenic zone are controlled by the zones of shear interaction of different dynamics and kinematics, which are spatially related to kimberlite pipes and diamond placer deposits. The results of this study imply that the method proposed for interpretation of gravity field can predict the occurrence of structures of geodynamic control of kimberlite magmatism of the Yakut diamond-bearing province.
\end{abstract}

KEYWORDS: kimberlite pipe; gravimetry; deformation; shear; shear interaction; transpression; extension; rock flow; fractality; mesomechanics

FOR CITATION: Makeev S.M., 2021. Structural-geodynamic control of kimberlite pipes of the Yakut diamond province according to the data of gravistructural analysis. Geodynamics \& Tectonophysics 12 (4), 992-1008. doi:10.5800/GT-2021-12-4-0567 


\title{
СТРУКТУРНО-ГЕОДИНАМИЧЕСКИЙ КОНТРОЛЬ КИМБЕРЛИТОВЫХ ТРУБОК ЯКУТСКОЙ АЛМАЗОНОСНОЙ ПРОВИНЦИИ ПО ДАННЫМ ГРАВИСТРУКТУРНОГО АНАЛИЗА
}

\author{
С.М. Макеев
}

Сибирский федеральный университет, 660041, Красноярск, пр-т Свободный, 79, Россия

АНнотАЦИЯ. В статье изложены главные положения нового метода интерпретации региональной гравиметрии (масштаб 1:1000000), основанные на представлении о деформационной природе низкочастотных аномалий гравитационного поля. Метод позволил установить направления тектонического сжатия территории Якутской алмазоносной провинции, локализовать участки и оси межсдвигового сжатия и растяжения разного кинематического знака и на их основе выделить зоны межсдвигового взаимодействия, пространственно коррелирующие с размещением кимберлитовых трубок. В частности, для всей территории провинции установлены четыре направления транспрессионного сжатия: пара ортогональных (правосдвиговое с азимутом $8^{\circ}$ и левосдвиговое - $98^{\circ}$ ) и пара диагональных (правосдвиговое - 38 и левосдвиговое $-128^{\circ}$ ). Эти данные согласуются с результатами региональных тектонофизических исследований не только по азимутам направлений сжатия, но и по кинематическим знакам транспрессионных движений для двух главных фаз геодинамической эволюции Якутской алмазоносной провинции - преимущественно правосдвиговых для первой фазы северо-восточного сжатия и левосдвиговых для второй фазы северо-западного сжатия.

Также в работе показано, что Алакит-Оленекская минерагеническая зона представляет собой протяженную ( 500 км) область пластической деформации горных пород шириной 90 км с правосторонней кинематикой кажущихся движений пород вдоль ее северной и южной границы. При этом южная граница минерагенической зоны представляет собой достаточно целостную структуру северо-восточного простирания, тогда как ее северная граница выражена фрагментарно. Границы Алакит-Оленекской минерагенической зоны контролируются зонами межсдвигового взаимодействия разного динамического и кинематического знака, с которыми установлена пространственная связь кимберлитовых трубок и алмазоносных россыпей. Полученные в ходе исследования результаты позволяют использовать предлагаемый метод интерпретации гравитационного поля для прогнозирования структур геодинамического контроля кимберлитового магматизма Якутской алмазоносной провинции.

КЛЮЧЕВЫЕ СЛОВА: кимберлитовая трубка; гравиметрия; деформация; сдвиг; межсдвиговое взаимодействие; транспрессия; растяжение; течение пород; фрактальность; мезомеханика

\section{1. ВВЕДЕНИЕ}

К настоящему времени сложились два взгляда на проблему регионального контроля кимберлитового магматизма Якутской алмазоносной провинции (ЯАП). Первый состоит в том, что цепочки кимберлитовых трубок контролируются линейными структурами разного генетического типа, порядка и направления - северо-восточного, северо-западного, реже - субширотного и еще реже - субмеридионального. Сами трубки и их кусты, как правило, размещаются в узлах пересечения таких структур. Подобного взгляда придерживается большинство исследователей на протяжении всей истории изучения этого вопроса, и его можно считать классическим [Odintsov, 1957; Trushkov, 1974; Milashev, 1979; Molchanov, Savrasov, 1981].

Второй взгляд на проблему начал складываться в последние 10-15 лет в результате тектонофизических исследований ИЗК СО РАН (г. Иркутск), проведенных на карьерах нескольких трубок в разных алмазоносных районах ЯАП. Данные исследования позволили сделать следующие выводы [Gladkov et al., 2008]:

1. В пределах кимберлитовых полей, далеко разнесенных в пространстве ЯАП, формирование трубок происходило в сходной геодинамической обстановке, присущей разломам разной ориентировки, но одного генетического типа.

2. Подавляющее большинство сопряженных пар трещин на изученных карьерах принадлежит к сдвиговому типу и связано со знакопеременными движениями по разломам в фундаменте и нижней части платформенного чехла. В пределах ЯАП установлены четыре пары взаимосвязанных геотектонических полей: 1) северо-восточного сжатия - северо-западного растяжения (трубки Таежная, Комсомольская, Юбилейная); 2) северо-западного сжатия - северо-восточного растяжения (трубки Таежная, Комсомольская, Юбилейная); 3) субмеридионального сжатия - субширотного растяжения (трубки Таежная, Комсомольская, Юбилейная) и 4) субширотного сжатия - субмеридионального растяжения (трубка Юбилейная).

3. Формирование и активизация разломно-блоковой структуры в пределах изученных карьеров сопровождается развитием субгоризонтальных разрывных нарушений, возникающих в результате межслоевых срывов и внутрислоевого течения пород.

4. Большинство изученных кимберлитовых тел, как было известно и ранее, приурочены к узлам пересечения север-северо-восточных и запад-северо-западных 
разрывных нарушений. Однако принципиальной новизной полученных решений является то, что практически все указанные узлы находятся на участках взаимодействия между кулисообразно сближенными сдвигами и имеют характерные черты дуплексных или пулл-апарт структур растяжения (рис. 1, a).

Данный вывод является ключевым и находит свое подтверждение в работах других исследователей [Ignatov et al., 2017], детально изучивших зоны межсдвиговых растяжений, вмещающих кимберлитовые тела, по данным бурения (рис. 1, б).

5. Цепочки трубок не всегда соответствуют линиям разломов, и все известные попытки анализа цепочечного выстраивания кимберлитовых тел в пределах известных полей ЯАП так и не привели к выявлению закономерностей в их распределении. Необходима разработка алгоритмов распознавания разномасштабных присдвиговых структур растяжения по комплексу геолого-структурных и геофизических данных.

Ниже рассмотрен новый метод интерпретации аномального гравитационного поля, который позволил выделить структуры межсдвигового взаимодействия в ЯАП и получить результаты, во многом созвучные с приведенными выводами.

\section{2. МЕТОДЫ}

Гравиструктурный метод исследования [Makeev, 2016] разработан на основе предположения, что карта аномального гравитационного поля в редукции Буге отражает все особенности пространственного распределения плотности горных пород, независимо от того, вызваны ли эти особенности распределением масс (числитель формулы плотности) в результате переноса вещества или же перераспределением объема пород (знаменатель формулы плотности) в результате тектонических деформаций. Поскольку в термодинамически открытой геологической среде разделить оба фактора практически невозможно, гравиструктурный метод построен как феноменологический и морфоструктурный.

Математической основой метода является частотно-азимутальный анализ, позволяющий разложить гравитационное поле на совокупность азимутальных состояний, каждое из которых представляет собой амплитудное распределение поля (аномалий экстремального типа) на одной пространственной частоте в одном азимутальном направлении. Морфоструктурный анализ отдельных азимутальных состояний позволяет выделять структуры двух типов:

1) первичные гравитационные дуплексы - пары конформных, относительно сближенных аномалий гравитационного поля противоположного знака, периклинально сопряженных между собой точками замыкания и часто нарушенных флексурными перегибами, в пределе переходящими в левые или правые сдвиги (рис. 1, в);

2) вторичные деформационно-сдвиговые зоны сжатия или растяжения - области между сдвигами одного кинематического знака, интерпретируемые как области право- или левосдвигового сжатия или растяжения (рис. 1, г). Для картирования деформационно-сдвиговых зон рассчитывается безразмерная величина межсдвигового потенциала:

$$
P=\frac{h}{4 l}(b+e)\left(\cos \alpha_{1}+\cos \alpha_{2}\right)
$$

учитывающая размеры $(b, e, l)$, степень геометрического искажения геологического пространства $\left(\cos \alpha_{1}\right.$, $\cos \alpha_{2}$ ) в межсдвиговой области деформационного параллелограмма (рис. 1 , д), а также функцию азимутального состояния поля $h$ (ФАС) - весовую функцию интегральной интенсивности поля вдоль азимута анализа. В силу того, что дуплексные аномалии биполярны по своей природе, интегрирование ФАС ведется по модулю.

Закономерное строение гравитационных дуплексов позволяет сформулировать гипотезу об их деформационной природе. Смысл гипотезы заключается в том, что действие горизонтальных составляющих тектонических сил на ограниченный в пространстве массив горных пород вызывает изгиб последнего, перераспределение объема микротрещин и пор, как следствие, плотности и в результате формирует биполярную, дуплексную, структуру гравитационных аномалий.

Основной причиной формирования структур второго типа - деформационно-сдвиговых зон, вероятно, является дилатансия - необратимое изменение объема горных пород в результате переупаковки межзернового пространства в процессе схлопывания или раскрытия трещин при микросдвиговых деформациях или катакластическом течении горных пород. По данным В.Н. Николаевского, из-за нелинейности скоростей протекания таких процессов их результаты локализуются в виде полос или зон скольжения, в пределах которых может происходить как дилатансионное сжатие, так и дилатансионное растяжение горных пород [Nikolaevsky, 2010]. Именно такие полосы скольжения и фиксируют, на наш взгляд, деформационно-сдвиговые зоны, занимающие секущее по отношению к аномалиям гравитационного поля положение (рис. 1, г).

Структурно-геологическими аналогами деформационно-сдвиговых зон являются присдвиговые структуры сжатия или растяжения, которые формируются в пространстве между сдвигами одного кинематического знака - дуплексы сжатия (реверсные структуры присдвигового сжатия) или дуплексы растяжения (пуллапарт структуры) [Twiss, Moores, 1992]. Дуплексные структуры обычны для многих сдвиговых систем геологической природы [Cowgill et al., 2000; Sarkarinejad, Azizi, 2008], а также изучаются экспериментально [Bornyakov, 1981; Sherman et al., 1983, 1991; Woodcock, Fisher, 1986]. При этом аналогично тому, что горные породы, независимо от их литологии и химизма, выполняют лишь роль носителей сдвиговых деформаций и межсдвиговых взаимодействий, можно полагать, что и дуплексные аномалии гравитационного поля, независимо от их 
знака и амплитуды, являются лишь носителями правых и левых сдвигов и взаимодействий между ними.

Таким образом, предметную область гравиструктурного метода исследования составляют дуплексные гравитационные аномалии, линии правых и левых сдвигов разнополярных аномалий дуплексов (рис. 1, в), отдельные области (в виде деформационных параллелограммов) и оси межсдвигового сжатия и растяжения, объединяемые в деформационно-сдвиговые зоны (рис. 1, г, д). При этом все вышеназванные объекты исследования (слои информации) относятся к тому или иному, отличному от других, азимутальному состоянию поля (его конфигурации при выбранном азимуте анализа) и могут комбинироваться друг с другом произвольным образом, исходя из поставленной задачи и способов суперпозиции.

Для выделения деформационно-сдвиговых зон сжатия и растяжения ЯАП и изучения пространственной
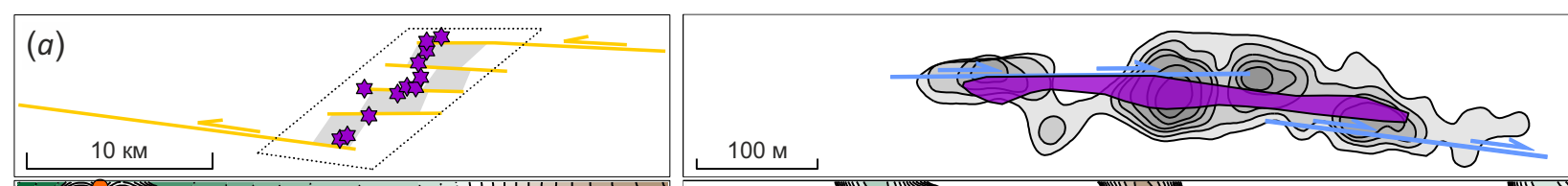

(б)
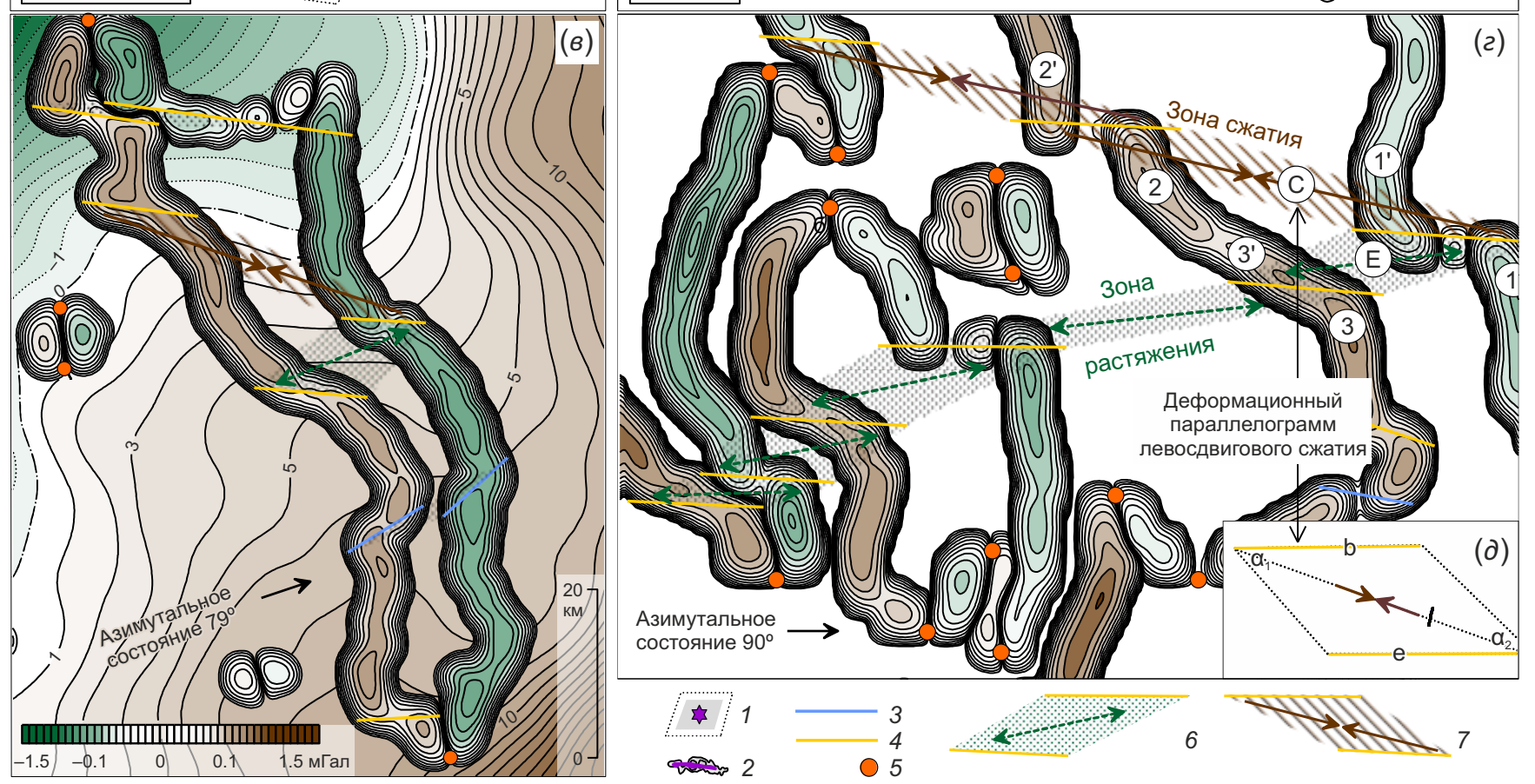

Рис. 1. Схемы размещения разномасштабных кимберлитовых объектов в зонах межсдвигового растяжения.

(a) - куст трубок в области левосдвигового растяжения в Алакит-Мархинском районе - 1 [Gladkov et al., 2008]; (б) - кимберлитовое тело Майского месторождения на участке правосдвигового растяжения в Накынском районе - 2 (изолинии серого цвета отражают интенсивность признаков растяжения в разведочных скважинах [Ignatov et al., 2017]). Основные элементы гравиструктурного анализа: (в) - гравитационный дуплекс на фоне измеренного поля (мГал); сдвиги: 3 - правые, 4 - левые; 5 - точки замыкания; (2) - дуплексная структура гравитационного поля в азимутальном состоянии $90^{\circ}$ и принцип выделения областей, осей и деформационно-сдвиговых зон левостороннего растяжения (6) и сжатия (7): если внутри области С между сдвигами одного кинематического знака разнополярные аномалии 2 и 1' относительно своих смежных частей 2' и 1 смещаются вдоль длинной оси деформационного параллелограмма навстречу друг другу, то область С интерпретируется как область сжатия. Если же в межсдвиговой области Е разнополярные аномалии 3' и 1 смещаются относительно своих смежных частей 3 и 1' друг от друга, то область Е интерпретируется как область растяжения; $(\partial)$ - геометризация размеров $(b, e, l)$ и углов деформации $\left(\alpha_{1}, \alpha_{2}\right)$ параллелограмма левосдвигового сжатия.

Fig. 1. Layouts of different-scale kimberlite objects in inter-shear extension zones.

(a) - a cluster of kimberlite pipes in the area of sinistral extension in the Alakit-Markha region - 1 [Gladkov et al., 2008]; (6) - kimberlite body of the Mayskoye field in the area of dextral extension in the Nakyn region - 2 (gray isolines reflect the intensity of extension in exploration wells [Ignatov et al., 2017]). Basic elements of gravistructural analysis are: ( $\theta$ ) - gravity duplex against the background of the field measured (mGal); shears: 3 - right-laterals, 4 - left-laterals; 5 - mating points; ( 2 ) - duplex structure of the gravitational field in the azimuthal state $90^{\circ}$ and the principle of identifying areas, axes and deformation-shear zones of left-lateral extension (6) and compression (7): if bipolar anomalies 2, 1' appear to be displaced towards each other along the long axix of the deformation parallelogram relative to their adjacent parts 2', 1 inside area $\mathrm{C}$ between the shears of the same kinematic sign, then area $\mathrm{C}$ is interpreted as an area of compression. If bipolar anomalies 3' and 1 appear to be displaced from each other along the long axis of the deformation parallelogram relative to their adjacent parts 3 and 1'inside E, then area E is interpreted as an area ofextension; (д) - geometrization of dimensions $(b, e, l)$ and deformation angles $\left(\alpha_{1}, \alpha_{2}\right)$ of the parallelogram of the sinistral compression. 
связи с ними кимберлитовых трубок были выполнены следующие исследования.

1. По матрице $2 \times 2$ км с шагом азимута $9^{\circ}$ выполнен частотно-азимутальный анализ аномального гравитационного поля в редукции Буге (источник данных: база данных «Гравимаг») территории ЯАП в контуре размещения 95 кимберлитовых трубок (источник данных: база данных ВСЕГЕИ). Для пространственной частоты 20 км$^{-1}$ выделены 20 азимутальных состояний - гравиструктурных карт, аналогичных по структуре рис. 1, в. На каждой из этих карт выделены правые и левые сдвиги, геометризированы области и оси право- и левосдвигового сжатия и растяжения (аналогичные по структуре рис. 1, г). Для каждой оси сжатия или растяжения рассчитан межсдвиговый потенциал $P$.

2. Проведен анализ азимутов простирания осей право- и левосдвигового сжатия и растяжения, а также правых и левых сдвигов, сформировавших эти оси. Всего на площади ЯАП 1 млн км² (рис. 2) были выявлены 1762 левых и 2028 правых сдвигов гравитационных аномалий, и на их основе геометризированы 378 и 440 осей лево- и правосдвигового сжатия, 657 и 770 осей лево- и правосдвигового растяжения соответственно; определены азимуты каждого из этих объектов.

3. Проведен анализ удаленности кимберлитовых трубок от осей лево- и правосдвигового сжатия или растяжения. Для этого строились распределения эмпирической удаленности $d$ трубки от ближайшей к ней оси сжатия или растяжения право- или левосдвиговой кинематики (рис. 3). Далее каждое из полученных распределений сопоставлялось с его случайным аналогом - распределением функции случайной удаленности $d_{0}$ (рис. 3). Последнее является генеральным, а его форма определяется фактическим пространственным распределением осей сжатия или растяжения в пределах площади анализа (рис. $3, a)$. Функция $d$ является частной выборкой из $d_{0}$, и ее распределение отклоняется от распределения $d_{0}$ на величину $\Delta d$ в той мере, в какой сближенность трубок с осями сжатия или растяжения носит неслучайный, закономерный характер.

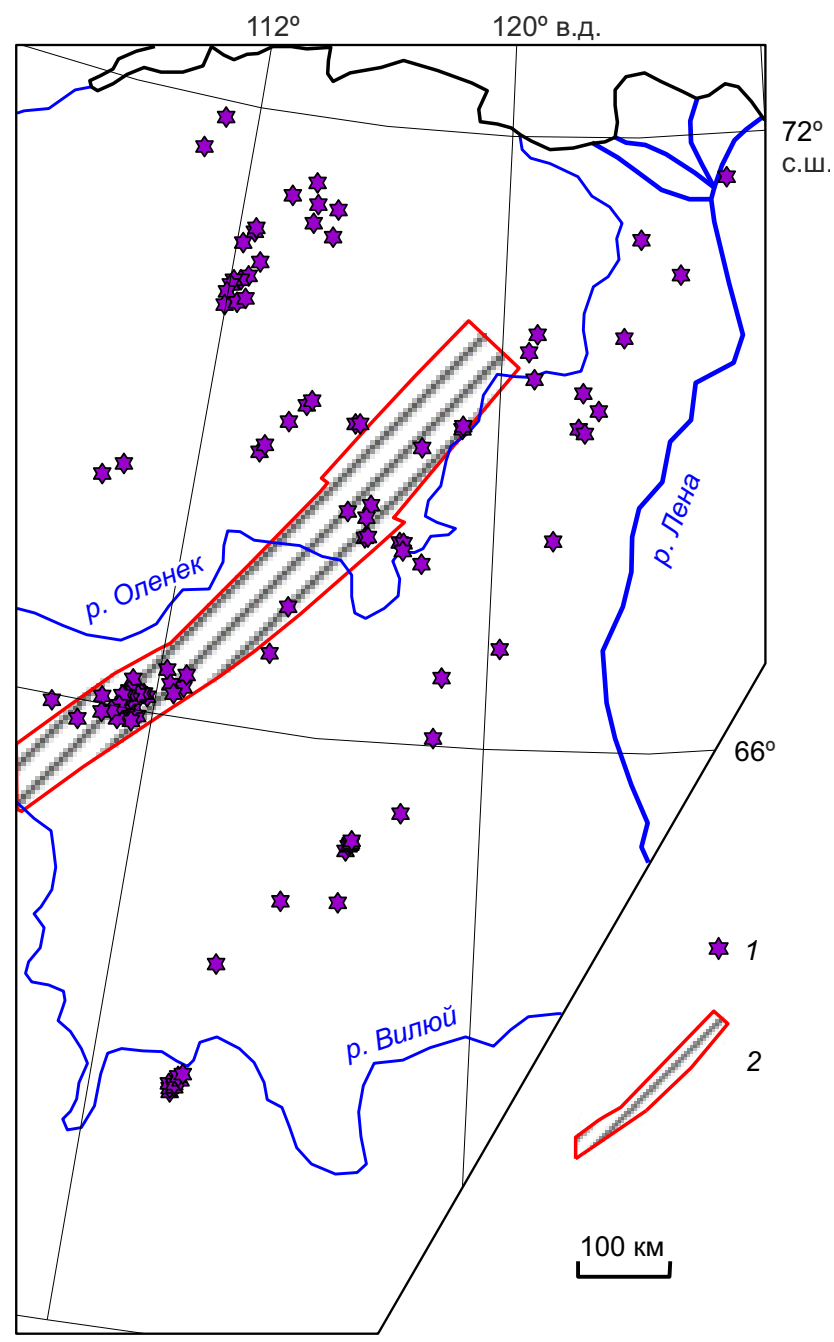

Рис. 2. Контур площади исследования ЯАП: 1 - кимберлитовые трубки; 2 - контур Алакит-Оленекской минерагенической зоны [Vaganov et al., 2002].

Fig. 2. Contour of the study area of the YDP: 1 - kimberlite pipes; 2 - contour of the Alakit-Olenek mineragenic zone [Vaganov et al., 2002]. 

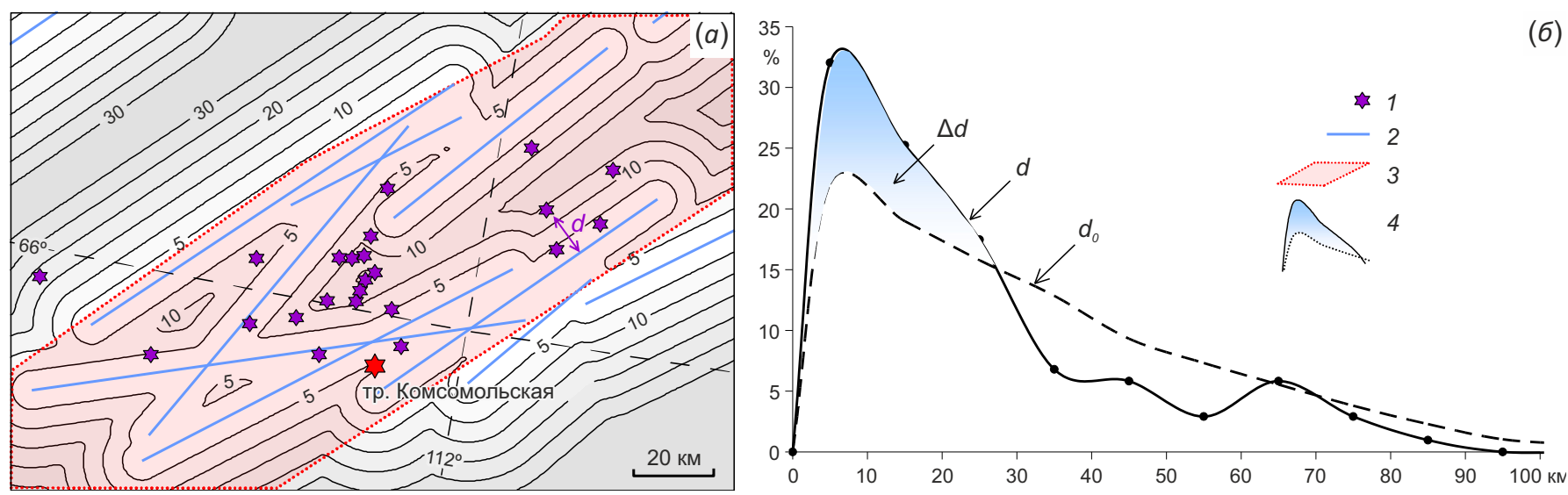

Рис. 3. Анализ пространственной корреляции трубок и осей межсдвигового взаимодействия.

(a) - положение трубок (1) относительно осей правосдвигового растяжения с азимутами простирания $38-83^{\circ}(2)$ в пределах фрагмента Алакит-Оленекской минерагенической зоны (3) на фоне изолиний функции случайной удаленности $d_{0}(\kappa м)$; (б) распределение функций эмпирической $(d)$ и случайной $\left(d_{0}\right)$ удаленности трубок ЯАП от указанных осей. Значения функций $d$ и $d_{0}$ оценивались как относительные доли трубок (для $d$ ) или узлов сетки (для $d_{0}$ ), находящихся на том или ином удалении от осей. Функция неслучайной удаленности $\Delta d(4)$ представляет собой положительное превышение функции $d$ над $d_{0}$; в данном случае эта функция является мерой неслучайности пространственной корреляции трубок и рассматриваемых осей в диапазоне удаленности 0-30 км.

Fig. 3. Analysis of the spatial correlation of pipes and axes of intershear interaction.

(a) - position of pipes (1) relative to the axes of sinistral tension with strike azimuths $38-83^{\circ}(2)$ within a fragment of the Alakit-Olenek mineragenic zone (3) against the background of isolines of the function of random distance $d_{0}(\mathrm{~km})$; ( 6 ) - distribution of functions of empirical $(d)$ and random $\left(d_{0}\right)$ distance of YDP pipes from the axes indicated. The values of functions $d$ and $d_{0}$ were estimated as relative fractions of pipes (for $d$ ) or grid nodes (for $d_{0}$ ) located more or less far from the axes. The function of non-random distance $\Delta d(4)$, which is the positive excess of function $d$ over $d_{0}$-is a measure of non-randomness of the spatial correlation of pipes and axes under consideration in 0-30 km range.

\section{3. РЕЗУЛЬТАТЫ}

На основе вышеизложенной модели интерпретации аномального гравитационного поля ЯАП получены следующие результаты.

1. Построены графики плотности распределения азимутов осей право- и левосдвигового сжатия и растяжения (рис. 4), на которых видно, что главные азимутальные моды право- и левосдвигового сжатия $(8,38,98$ и $128^{\circ}$ ) соответствуют направлениям сжатия (субмеридиональному, северо-восточному, субширотному и северо-западному), установленным по данным вышеуказанного тектонофизического исследования [Gladkov et al., 2008]. При этом соответствуют не только направления, но и кинематические знаки транспрессивных движений для двух главных фаз тектонического сжатия ЯАП - преимущественно правосдвиговых для первой фазы северо-восточного сжатия и левосдвиговых для второй фазы северо-западного сжатия (рис. 4, а).

В противоположность этому результату азимутальные моды осей межсдвигового растяжения, выделенные по данным гравиструктурного анализа, не соответствуют направлениям растяжения, выделенным по данным тектонофизического анализа (рис. 4, б), то есть взаимная ортогональность направлений сжатия и растяжения, являющаяся одной из констант тектонофизики хрупкого разрушения горных пород, для осей межсдвигового сжатия и растяжения, выделенных по данным гравиструктурного анализа, нарушается.
2. На основе базы данных из 3790 азимутов правых и левых сдвигов с модами азимутального распределения осей право- и левосдвигового сжатия и растяжения были сопоставлены соответствующие им моды азимутального распределения правых и левых сдвигов (рис. 5). Для этого в четырех распределениях на рис. 4 вокруг азимутальных мод 0 , 8, 38, 53, 60, 83, 98, 128 и $143^{\circ}$ осей того или иного типа межсдвигового взаимодействия был рассмотрен \pm 15 -градусный диапазон азимутов. В частности, для осей правосдвигового сжатия 8, 38 и $98^{\circ}$ рассматривались диапазоны азимутов $173-23^{\circ}, 23-53^{\circ}$ и $83-113^{\circ}$; для осей левосдвигового сжатия 53, 98 и $128^{\circ}$ - диапазоны $38-68^{\circ}, 83-113^{\circ}$ и $113-143^{\circ}$; для осей правосдвигового растяжения 60 и $143^{\circ}$ - диапазоны $38-83^{\circ}$ и $128-158^{\circ}$; наконец, для осей левосдвигового растяжения 0,38 и $83^{\circ}$ - диапазоны $165-15^{\circ}, 23-53^{\circ}$ и $68-98^{\circ}$ соответственно. Из этих диапазонов выбирались все частные оси, сформировавшие рассматриваемую моду. И поскольку каждая частная ось взаимодействия образуется парой сдвигов (см. рис. 1, в, г), из множества азимутов последних была выделена и их мода. Таким образом, каждая мода оси межсдвигового взаимодействия, рассмотренная в своем \pm 15 -градусном диапазоне азимутов, находится в однозначном соответствии с модой сформировавших ее сдвигов (рис. 5). Полученные взаимные ориентации осей взаимодействия и сдвигов не противоречат теоретически однозначным соответствиям 

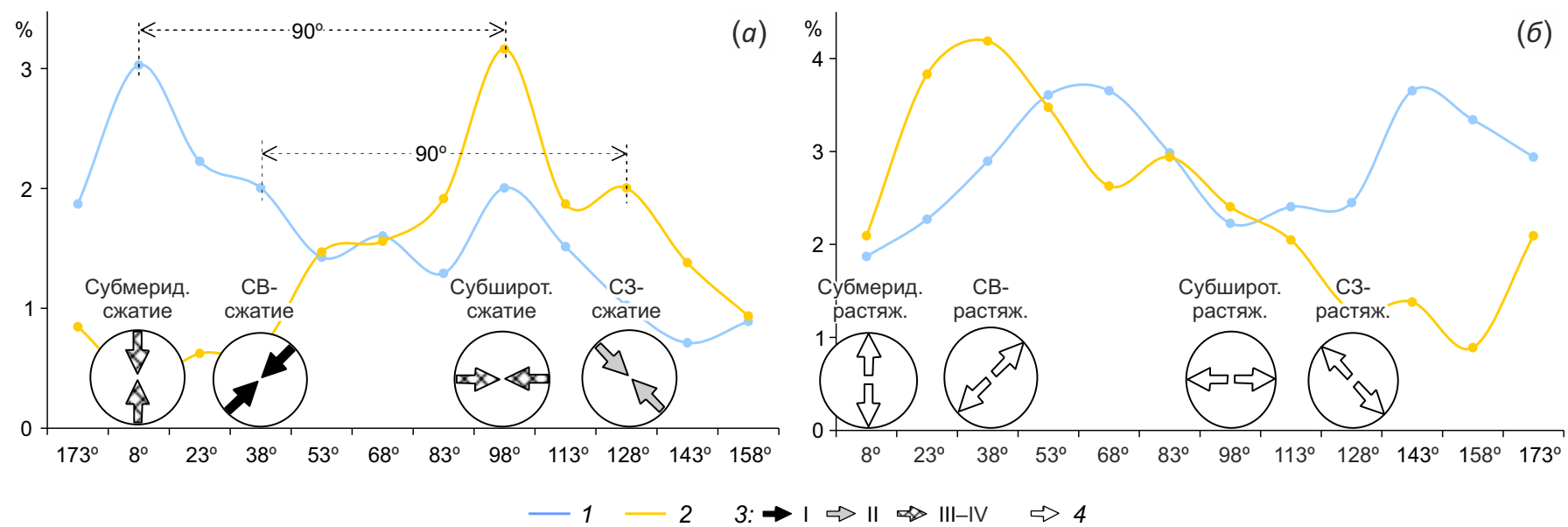

$-1-2 \quad 3: \Rightarrow 1 \Rightarrow I I \Rightarrow I I-I V \Rightarrow 4$

Рис. 4. Сопоставление результатов гравиструктурного (графики плотности распределения азимутов осей: 1 - право-, 2 левосдвигового сжатия $(a)$, растяжения (б) ) и тектонофизического анализа ЯАП (3 - направления сжатия четырех этапов тектонических движений: I - правосдвигового северо-восточного, II - левосдвигового северо-западного, III-IV - движений с неоднозначной кинематикой; 4 - направления растяжения) [Gladkov et al., 2008]. Ординаты на графиках даны в процентах от общего количества выявленных осей сжатия и растяжения (818 и 1427 соответственно).

Fig. 4. Comparison of the results of gravistructural (graphs of the distribution density of the azimuths of the axes: 1 - right-, 2 - leftlateral: (a) - compression, (б) - extension) and tectonophysical analyses of the YDP (3 - directions of compression of four-stage tectonic movements: I - dextral northeastern, II - sinistral northwestern, III-IV - movements with ambiguous kinematics; 4 - directions of extension) [Gladkov et al., 2008]. The ordinates in the graphs are given as a percentage of the total number of compression and extension axes revealed (818 and 1427 respectively).

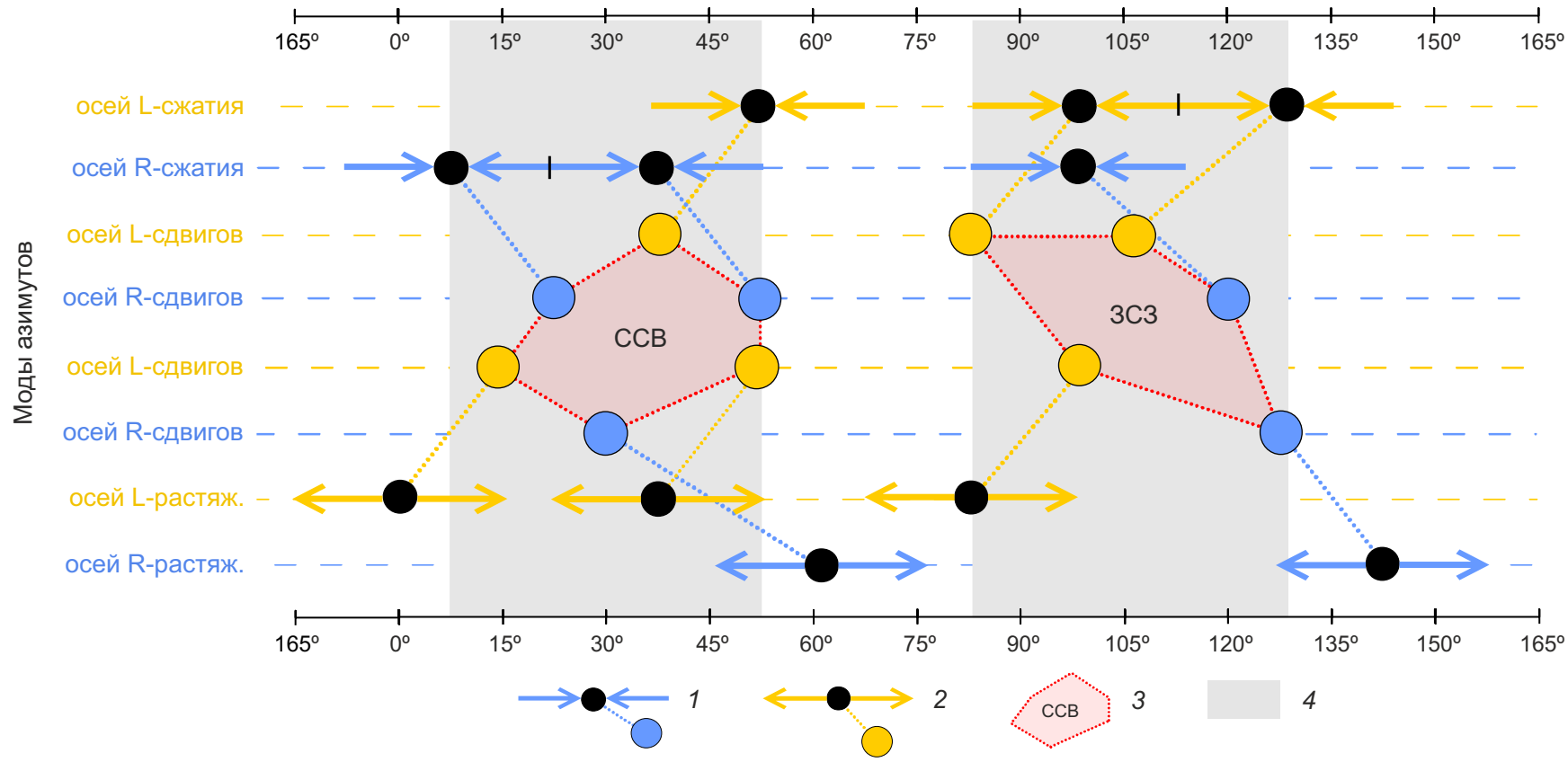

Рис. 5. Схема сопоставления азимутальных мод (черные точки в центрах \pm 15 -градусных диапазонов азимутов) осей межсдвигового сжатия (1) и растяжения (2) с модами левых (L, оранжевый цвет) и правых (R, синий цвет) сдвигов.

Моды сдвигов собрались в две азимутальные группы (3), которые лежат в двух полосах межсдвигового сжатия (4) - правостороннего север-северо-восточного и левостороннего запад-северо-западного.

Fig. 5. Scheme of comparison of azimuthal modes (black dots in the centers of \pm 15 -degree azimuth ranges) of the inter-shear compression (1) and extension (2) axes with the modes of left (L, orange) and right (R, blue) shears.

Note that shear modes make up two azimuthal groups (3), which lie in two inter-shear compression bands (4) - dextral north-northeastern and sinistral west-northwestern. 
азимутов правых $\left(A_{R}\right)$ и левых $\left(A_{L}\right)$ сдвигов и азимутов осей межсдвигового сжатия $\left(\mathrm{A}_{\text {сом }}\right)$ и растяжения $\left(\mathrm{A}_{\mathrm{EXT}}\right)$ : $A_{R}>A_{\text {сом-R }}, A_{R}<A_{\text {EXт-R, }}, A_{L}<A_{\text {сом-L' }}, A_{L}>A_{\text {Ехт-L }}$ Часть этих соответствий видна на рис. 1, г.

Из построенной схемы сопоставления следует, что азимуты правых и левых сдвигов гравитационных аномалий ЯАП собраны в две азимутальные полосы сжатия 8-53 и 83-128 - север-северо-восточного (ССВ) правосдвигового и запад-северо-западного (ЗСЗ) левосдвигового соответственно. Аналогичные направления сжатия получены и по данным тектонофизического исследования (см. рис. 4 , а).

3. Для двух азимутальных секторов - СВ (0-90) и С3 $\left(90-180^{\circ}\right)$, включающих в себя полосы правосдвигового ССВ и левосдвигового ЗСЗ сжатия (рис. 5), на основе анализа функции удаленности $d$ (см. рис. 3) были рассчитаны функции неслучайной удаленности $\Delta d$ кимберлитовых трубок ЯАП от осей межсдвигового взаимодействия в следующих диапазонах их азимутов: для сектора СВ (рис. 6, а) - в диапазонах $173-53^{\circ}$ и $38-83^{\circ}$ (для осей правосдвигового сжатия и растяжения соответственно) и в диапазонах $38-68^{\circ}$ и $165-53^{\circ}$ (для осей левосдвигового сжатия и растяжения соответственно), для сектора С3 (рис. 6, б) - в диапазонах $83-143^{\circ}$ и $68-98^{\circ}$ (для осей левосдвигового сжатия и растяжения соответственно) и в диапазонах $83-113^{\circ}$ и $128-158^{\circ}$ (для осей правосдвигового сжатия и растяжения соответственно).

Установлено, что в СВ азимутальном секторе оси правосдвигового сжатия и растяжения коррелируют с кимберлитовыми трубками более тесно, чем левосдвигового. При этом важно отметить, что сдвиги, формирующие оси правосдвигового растяжения, коррелируют с трубками слабее, чем сами оси растяжения. Аналогичная тенденция характерна и для сдвигов, формирующих оси левосдвигового растяжения в секторе СЗ. Также видно, что в СЗ азимутальном секторе левосдвиговые оси сжатия и растяжения коррелируют с трубками существенно лучше, чем в СB.

Полученные результаты позволяют утверждать, что ни кинематический (правый или левый), ни динамический (сжатие или растяжение) знак осей взаимодействия не являются достаточными условиями их лучшей пространственной корреляции с кимберлитовыми телами. Единственно важным в этом отношении фактором является азимут структур межсдвигового взаимодействия.

4. Для осей межсдвигового взаимодействия СВ азимутального сектора ЯАП, представляющих собой совокупность осей правосдвигового сжатия (взятых в диапазоне их азимутов $173-53^{\circ}$ ) и осей право- и левосдвигового растяжения (взятых соответственно в диапазонах азимутов $38-83^{\circ}$ и 68-98), был рассчитан суммарный потенциал межсдвигового взаимодействия $P$ вдоль указанных осей и построена его карта. На фрагменте этой карты (рис. 7) видно, что аномалии потенциала межсдвигового взаимодействия представляют собой систему полигональных структур разной протяженности, азимутальной выдержанности и степени замкнутости ее частей. Вдоль южной границы АлакитОленекской минерагенической зоны аномалии потенциала межсдвигового взаимодействия представляют собой протяженную азимутально-ломаную структуру северо-восточного простирания, тогда как вдоль северной границы этой зоны аномалии потенциала межсдвигового взаимодействия выражены лишь фрагментарно.
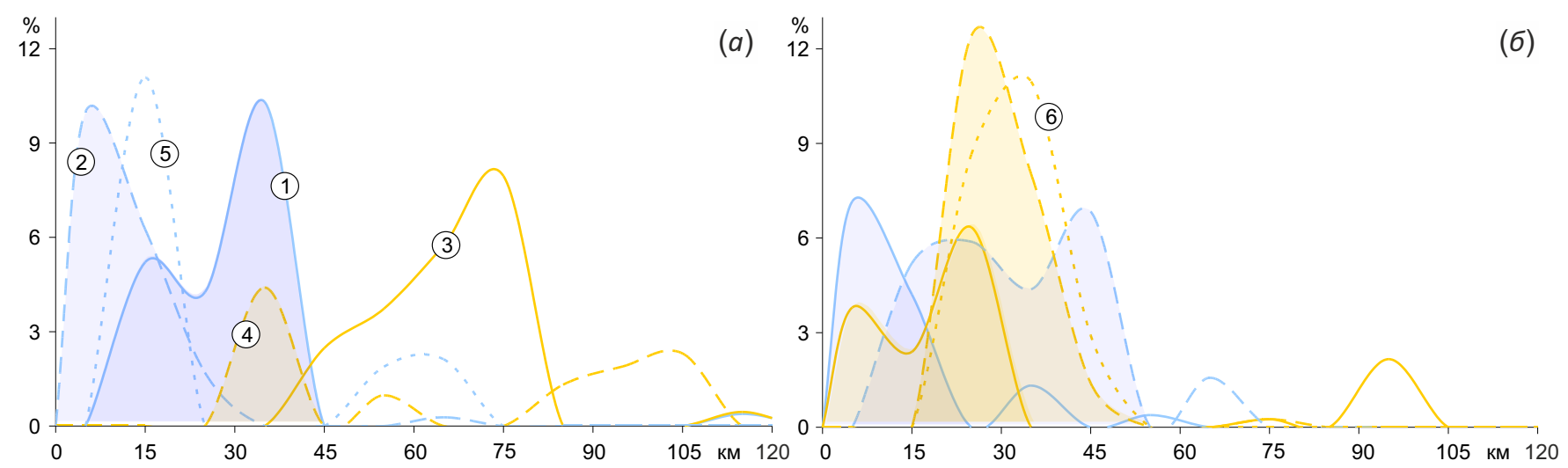

Рис. 6. Функция неслучайной удаленности $\Delta d$ кимберлитовых трубок ЯАП от осей сжатия: 1 - правосдвигового, 3 - левосдвигового; от осей растяжения: 2 - правосдвигового, 4 - левосдвигового в двух азимутальных секторах: $(a)-\mathrm{CB}\left(0-90^{\circ}\right)$, (б) - С3 $\left(90-180^{\circ}\right)$.

Значения функции $\Delta d$ рассчитывались так же, как и на рис. 3, б. Оси правосдвигового растяжения (2) в секторе СВ и оси левосдвигового растяжения (4) в секторе С3 связаны с кимберлитовыми трубками теснее, чем формирующие их правые (5) и левые (6) сдвиги.

Fig. 6. Function of non-random distance $\Delta d$ between the YDP kimberlite pipes and compression axes: 1 - dextral, 3 - sinistral; between the pipes and extension axes: 2 - dextral, 4 - sinistral in two azimuthal sectors: $(a)-\mathrm{NE}\left(0-90^{\circ}\right)$ and $(\sigma)-\mathrm{NW}\left(90-180^{\circ}\right)$. The values of function $\Delta d$ were calculated in the same way as in Fig. 3, 6 .

Note that the axes of dextral extension (2) in the NE sector and the axes of sinistral extension (4) in the NW sector are more closely related to kimberlite pipes than their forming dextral (5) and sinistral (6) shears. 


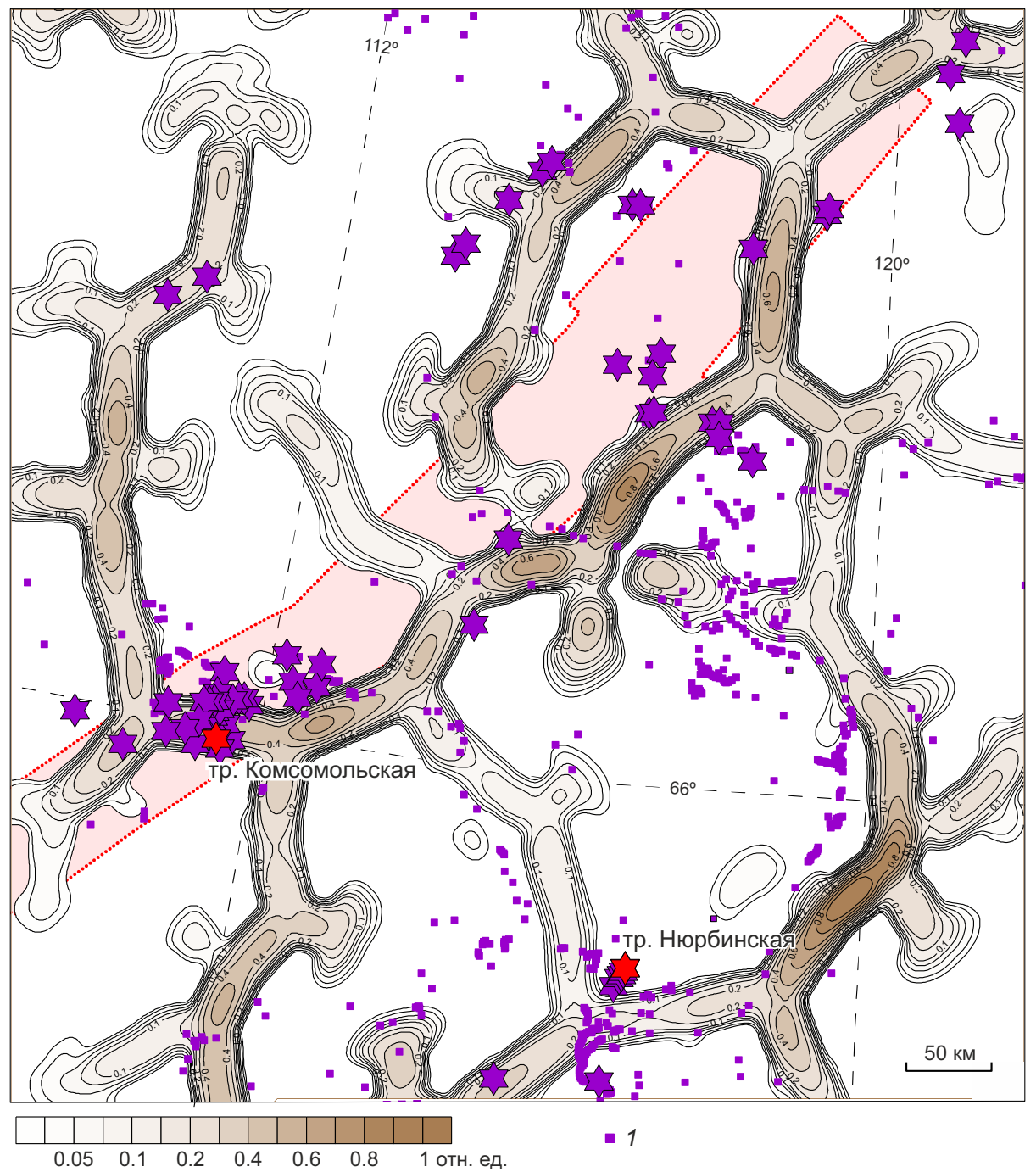

Рис. 7. Фрагмент карты суммарного потенциала межсдвигового взаимодействия структур СВ азимутального сектора (знакопеременных осей сжатия и растяжения в диапазоне азимутов 173-98) вдоль Алакит-Оленекской минерагенической зоны: 1 - аллювиальные россыпи и шлиховые находки алмазов. Другие обозначения см. на рис. 3.

Fig. 7. Fragment of the map of the total potential of the shear interaction of the structures in the NE-azimuthal sector (sign-changing axes of compression and extension in the azimuth range $173-98^{\circ}$ ) along the Alakit-Olenek mineragenic zone: 1 - alluvial placers and placer finds of diamonds. Other designations are given in Fig. 3.

Но при всей сложности внутреннего строения структур межсдвигового взаимодействия (представляющих собой знакопеременные оси сжатия и растяжения в диапазоне азимутов $173-98^{\circ}$ ) они хорошо контролируют размещение как кимберлитовых трубок, так и алмазоносных россыпей ЯАП, что позволяет использовать этот вид геодинамических структур в целях регионального прогнозирования.

\section{4. ОБСУЖДЕНИЕ}

Одним из интригующих вопросов настоящего исследования остался вопрос, вытекающий из анализа рис. 4: почему при качественном соответствии азимутального распределения осей сжатия, выделенных и тектонофизическим, и гравиструктурным методами, таковое соответствие полностью «развалилось» для осей растяжения? Предпринятые автором попытки выделить по данным гравиструктурного анализа сопряженные системы сдвигов, не противоречащие принципам тектонофизической интерпретации сколовых трещин (также сдвиговых по своей природе), ни к чему не привели.

Из непротиворечивости результатов, полученных двумя независимыми методами в отношении направлений сжатия, возникло предположение, что тектоническое сжатие следует признать инициальной первопричиной всей геодинамической эволюции ЯАП, тогда как последующее растяжение геологического пространства носит вторичный, релаксационный, характер и может по-разному проявляться при разных типах деформаций - хрупких и пластических.

Для проверки этого предположения из всего многообразия низкочастотных азимутальных состояний гравитационного поля ЯАП было подобрано состояние $42^{\circ}$, 
которое наиболее контрастно отражает процесс «тектонического течения» горных пород вдоль АлакитОленекской минерагенической зоны (рис. 8).

Выявленная картина наглядно показывает наличие двух групп противоположно направленных деформаций гравитационных аномалий - деформаций, имеющих характерную морфологию надвигового типа с торцевыми сдвигами разной кинематики. Соединив центральные части смежных деформаций надвиговой морфологии в направлении их кажущегося движения (надвигания) двумя «линиями течения», получим широкую ( 90 км) зону с азимутом простирания $\sim 30^{\circ}$ и правосторонней кинематикой «линий течения», практически точно совпадающих с границами Алакит-Оленекской минерагенической зоны. Сопоставив «линии течения» с вышеустановленными аномалиями потенциала

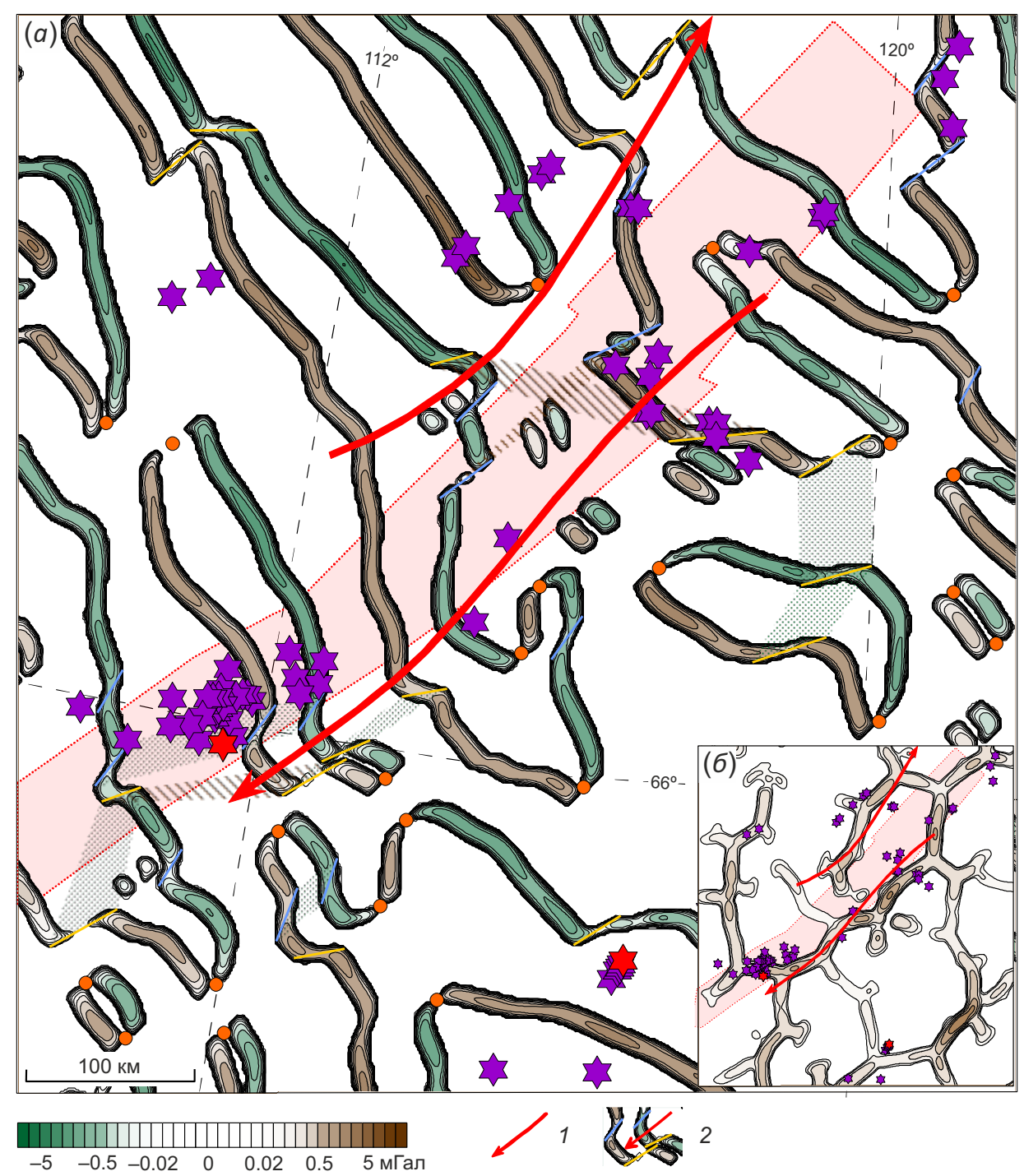

Рис. 8. Карта относительных аномалий низкочастотной $\left(36\right.$ км$\left.^{-1}\right)$ составляющей гравитационного поля (в азимутальном состоянии $42^{\circ}$ ) вдоль Алакит-Оленекской минерагенической зоны (a). Линии течения (1), проведенные через элементы (2) гравитационных аномалий надвиговой морфологии (ограниченных торцевыми сдвигами разной кинематики), проходят вдоль северной и южной границы указанной зоны. Направления линий течения прямо указывают направления переноса избыточной плотности пород. Угол между торцевыми правыми и левыми сдвигами весьма мал - как правило, меньше допустимого угла между сопряженными сдвигами-сколами при хрупких деформациях горных пород (обычно этот угол больше $60^{\circ}$ ). Линии течения практически точно совпадают с аномалиями потенциала межсдвигового взаимодействия вдоль границ Алакит-Оленекской минерагенической зоны (б). Недостающие обозначения см. на рис. 1 и 3.

Fig. 8. Map of relative anomalies of the low-frequency $\left(36 \mathrm{~km}^{-1}\right)$ component of the gravitational field (in an azimuthal state $\left.42^{\circ}\right)$ along the Alakit-Olenek mineragenic zone ( $a$ ). The directions of flow (1) drawn through the elements (2) of gravity anomalies of thrust morphology (limited by end shears of different kinematics) run along the northern and southern boundaries of the indicated zone. The directions of the flow lines indicate the direction of the transfer of excess rock density. The angle between the dextral and sinistral end shears is very small - as a rule, less than the permissible angle between conjugated shears which occur during brittle deformations of rocks (usually this angle is more than $60^{\circ}$ ). The flow lines almost exactly coincide with the anomalies of the shear interaction potential along the boundaries of the Alakit-Olenek mineragenic zone (б). For other designations, see Fig. 1 and 3. 
межсдвигового взаимодействия (рис. 8, б), можно прийти к следующему заключению. Алакит-Оленекская зона представляет собой протяженную ( 500 км) зону пластической деформации геологического пространства с правосторонней кинематикой кажущегося течения пород и интенсивными межсдвиговыми взаимодействиями вдоль ее границ. Сами эти границы, а также зоны межсдвигового взаимодействия вокруг них статистически неслучайным образом коррелируют с кимберлитовыми трубками, аллювиальными россыпями и шлиховыми находками алмазов.

Таким образом, возникшее противоречие между результатами гравиструктурного и тектонофизического анализа ЯАП может быть снято следующим образом. Если ведущим фактором геодинамической эволюции ЯАП признать тектоническое сжатие, то направления стресса устанавливаются обоими методами непротиворечивым образом (см. рис. 4, а). Но поскольку тектонофизические исследования базируются на теории механического разрушения горных пород и локализованы на весьма ограниченных полигонах (карьерах трубок) или в керне скважин, они регистрируют непротяженные фрагменты хрупкого растяжения горных пород - сколовые трещины сдвиговой природы. Гравиструктурный же метод оперирует объектами регионального масштаба - сдвигами низкочастотных гравитационных аномалий протяженностью десятки километров. На таких масштабах растяжение горных пород не может быть осуществлено лишь хрупкими деформациями, а может происходить и пластически - в форме их кажущегося течения (подтверждением которого пока является только морфология самих гравитационных аномалий на рис. 8). Этим и можно объяснить противоречивость результатов обсуждаемых методов в отношении осей растяжения.

Второй момент, на котором необходимо остановиться, - это кажущийся характер течения пород, выявленного гравиструктурным методом. Говоря о течении пород, следует иметь в виду, что гравиметрия в общем случае «видит» перенос не самого вещества пород, а только их избыточной плотности (и то не прямо, а через изменение поля ускорения свободного падения). Но осуществить перенос плотности можно двумя способами - или за счет переноса массы, или за счет переноса (изменения) объема. В заполненной сплошь веществом геологической среде второе осуществить энергетически легче, поэтому кажущееся (с позиции гравиметрии) течение горных пород возникает, вероятнее всего и в первую очередь, не за счет прямого переноса их массы, а за счет переноса (изменения) их объема - за счет деформации пород.

Отсюда вытекает два следствия. Во-первых, некорректно делать прямые сопоставления методов, основанных на видимых изменениях самих пород (в частности, трещиноватости), с геофизическими методами, основанными на изменениях их (пород) физических свойств, в формулы которых прямо или косвенно входит объем горных пород, т.е. фактор деформации.
Во-вторых, способность гравиметрии зафиксировать в структуре поля самые первые (ранние) элементы движения горных пород (в виде необратимого изменения их объема) позволяет несколько иначе взглянуть на проблему изучения внутренней структуры сдвиговых разломных зон. В работе [Seminsky, 2003] установлено, что единая протяженная линия магистрального сместителя появляется у разломов только на самой поздней стадии их развития - стадии полного разрушения (рис. 9). На самых же ранних дизъюнктивных стадиях развития разломы представляют собой широкие геодинамические зоны сдвигового типа, в которых одновременно функционируют во взаимодействии локальные сдвиги разного кинематического знака и азимута (например, синтетические $R$ - и антитетические $R^{\prime}$-сдвиги Риделя). Но именно на этих ранних этапах развития сдвиговых систем происходит деформационное упрочнение горных пород и накопление в них упругой энергии (участок ОАВ на кривой «нагрузка $(\sigma)$ - деформация $(\varepsilon) »$ на рис. 9), т.е. создаются благоприятные условия для внедрения эксплозивных тел, в том числе кимберлитов, поэтому изучение геодинамических сдвиговых зон с помощью деформационночувствительных геофизических методов (прежде всего гравиметрии) позволяет более точно по смыслу и представительно по площади исследования приблизиться к решению геологических задач, связанных с прогнозированием кимберлитовых трубок и других объектов флюидодинамической природы.

Наконец последний важный момент, на котором необходимо остановиться, объяснить, каким образом новый метод интерпретации гравиметрических данных (назовем его деформационно-сдвиговым концептом интерпретации) соотносится с устоявшимся блоковоинтрузивным концептом интерпретации. Последний учитывает, прежде всего, недеформационные причины формирования гравитационных аномалий: влияние неоднородностей в распределении масс верхней части разреза, гранитоидных и базитовых интрузий, выступов кристаллического фундамента и границы кора - мантия.

Если рассмотреть частотное и азимутальное распределение ранее введенной функции азимутального состояния (ФАС) гравитационного поля ЯАП (рис. 10), то можно установить следующие закономерности (характерные и для других изученных нами территорий). Во-первых, максимум ФАС всегда фиксируется в ограниченном диапазоне пространственных частот (2040 км $^{-1}$ на рис. 10, а) с одной-двумя азимутальными модами (50 и $130^{\circ}$ на рис. 10, б). Во-вторых, с изменением пространственной частоты происходит эволюция азимутальных мод от слабовыраженных высокочастотных (4-8 км ${ }^{-1}$ на рис. 10, б) через один среднечастотный максимум (30 км ${ }^{-1}$ на рис. 10, б) до появления дополнительного низкочастотного (70 км ${ }^{-1}$ на рис. 10, б). В-третьих, разным регионам присущи свои характеристические (наиболее «яркие») азимутальные моды среднечастотного максимума ФАС. Для ЯАП это мода $50^{\circ}$ 


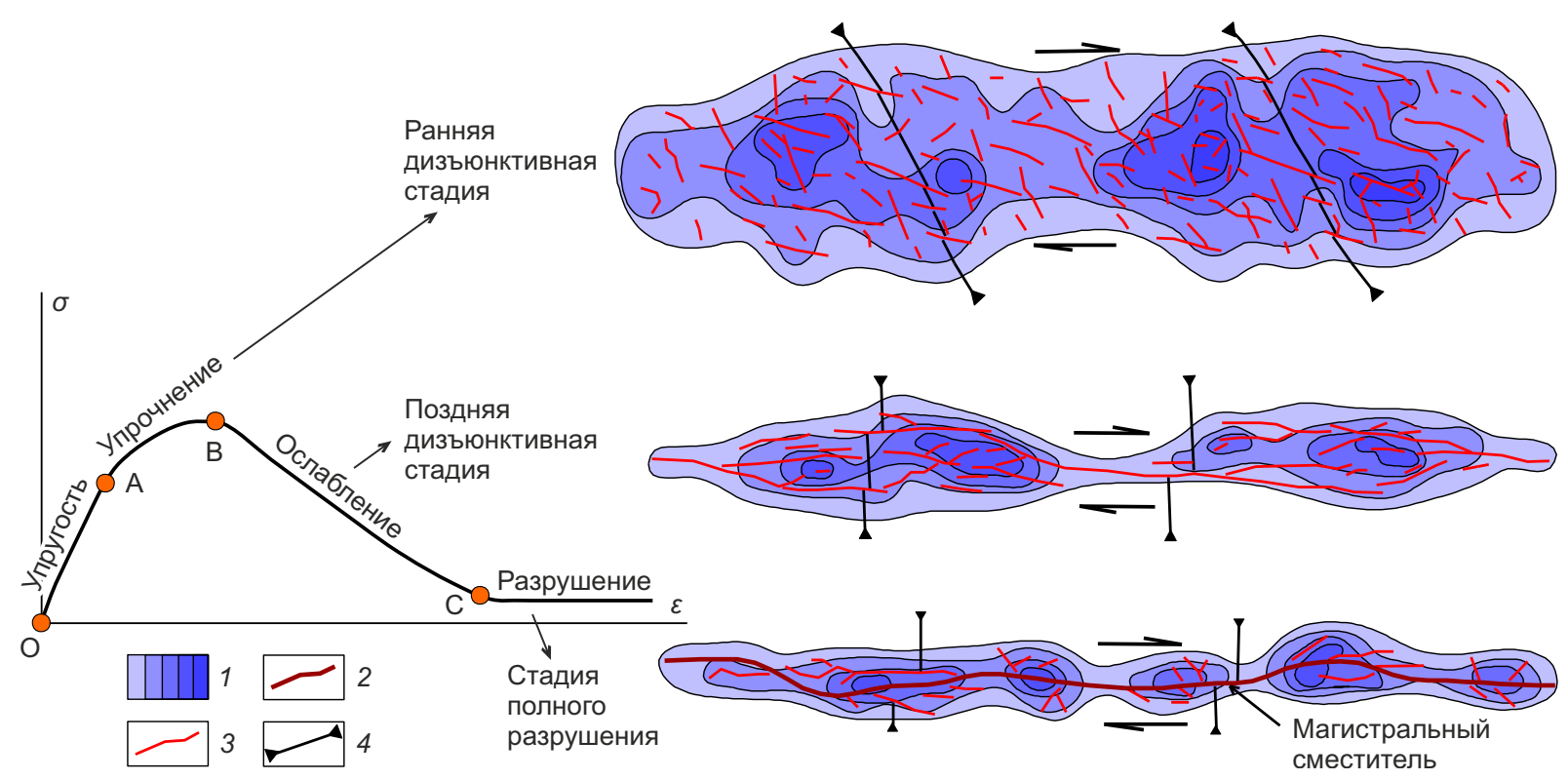

Рис. 9. Принципиальная схема формирования внутренней структуры сдвиговой разломной зоны на примере правого сдвига. 1 - участки с различным количеством разрывов в единице площади; 2 - магистральный сместитель 1-го порядка; 3 - сместители 2-го порядка; 4 - реперные линии. Главные стадии разрывообразования соответствуют трем характерным отрезкам на кривой «нагрузка $(\sigma)$ - деформация $(\varepsilon)$ » [Seminsky, 2003]. Максимальное накопление внутренней энергии в горных породах происходит на ранней дизъюнктивной стадии, когда информативность визуальных методов фиксации сдвиговых деформаций и межсдвиговых взаимодействий минимальна в силу ограниченности по площади полигонов наблюдений.

Fig. 9. A schematic diagram of the formation of the inner structure of the dextral strike-slip fault.

1 - areas with a different number of faults per unit area; 2 - main fault plane of the $1^{\text {st }}$ order; 3 - faults of the $2^{\text {nd }}$ order; 4 - reference lines. The main stages of fracturing correspond to three characteristic segments on the "load $(\sigma)$ - deformation $(\varepsilon)$ " curve [Seminsky, 2003]. Maximum accumulation of internal energy in rocks occurs at the early disjunctive stage, when the informativity of visual methods for recording shear deformations and shear interactions is minimal due to the limited testing-site areas.
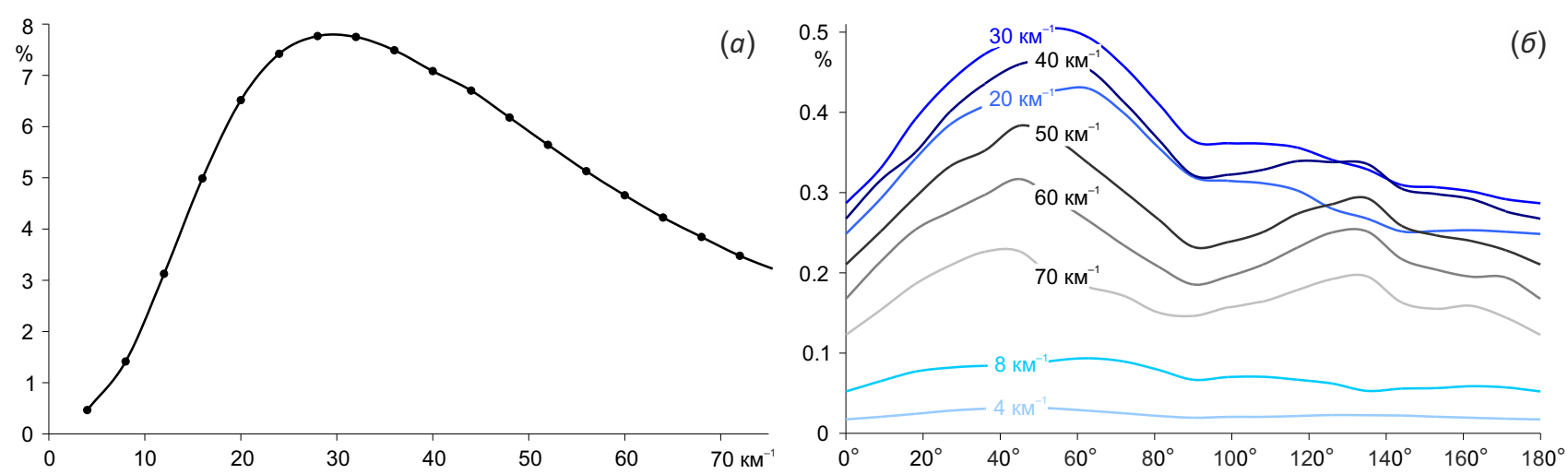

Рис. 10. Частотное $(a)$ и азимутальное (б) распределение функции азимутального состояния площади ЯАП. Частные значения этой функции даны в процентах от суммарного значения на всех пространственных частотах.

Fig. 10. Frequency $(a)$ and azimuthal (б) distributions of the azimuthal state function of the YDP area. The particular values of this function are given as a percentage of the total value at all spatial frequencies.

(рис. 10, б), для Енисейского кряжа - 70, Алтае-Саянской области $-5^{\circ}$, Западной Австралии - 90, Западной Камчатки - $20^{\circ}$ и т.д.

Кроме этого, для разных видов геофизических полей (гравитационное, магнитное и электрическое), измеренных в пределах одного региона, функция азимутального состояния демонстрирует еще одну очень важную закономерность, выявленную пока в пределах двух складчатых областей - Енисейской и Алтае-
Саянской. Она заключается в том, что независимо от масштаба съемки и видов полей азимутальные структуры последних подобны друг другу. Подобие проявляется в том, что максимум ФАС фиксируется в одном относительно узком диапазоне азимутов $\left(5 \pm 20^{\circ}\right.$ на рис. 11, а).

Объяснить выявленные закономерности - наличие среднечастотного максимума и пространственной анизотропии ФАС, а также масштабную и межвидовую 
инвариантность геофизических полей - наиболее просто, на наш взгляд, с позиций деформационно-сдвигового концепта интерпретации, положив в его основу две известные идеи. Первая высказана академиком М.А. Садовским и заключается в том, что иерархически-блочное строение горных пород на всех масштабных уровнях земной коры является фундаментальным свойством геологической среды [Sadovsky, 1979]. Эта идея открыла путь к обоснованию универсального принципа фрактальной делимости твердых тел, начиная с микроскопических размеров, сопоставимых с размерами кристаллической решетки, и заканчивая макроскопическими тектоническими блоками горных пород [Makarov, 2007]. Вторая идея, выдвинутая академиком В.Е. Паниным и активно развиваемая его последователями, состоит в том, что пластические деформации твердых тел (сопровождающиеся непрерывным накоплением в них деструктивных изменений вплоть до момента разрушения) развиваются как иерархически многоуровневый самоподобный (фрактальный) процесс, одновременный сразу на нескольких пространственных масштабах [Panin, 1998]. При этом носителями деформационного процесса на стадиях, предшествующих разрушению, являются средние (занимающие промежуточное положение между микро- и макроуровнями) мезоуровни, главными типами движения вещества на которых являются вращение относительно жестких доменов и сдвиги, концентрирующиеся в полосах пластического течения. Концепция мезомеханики, основанная на понятии среднего уровня как ключевого уровня анализа деформаций в любом диапазоне исследуемых масштабов, оказалась одинаково плодотворной для изучения как поликристаллических материалов, так и геосред [Gol'din, 2002].

Исходя из этих двух идей, можно предположить, что геофизические поля (в частности, на рис. 11, а) отражают не столько статическое (блоково-интрузивный концепт интерпретации), сколько динамическое состояние геологического пространства. Тогда наличие среднечастотного максимума ФАС (см. рис. 10, а) прямо фиксирует характеристическую пространственную частоту мезоуровня, на котором деформационный процесс при данном масштабе изучения наиболее контрастен. Наличие выраженной азимутальной моды на частоте мезоуровня (кривая 30 км $^{-1}$ на рис. 10, б) показывает преобладающее направление деформационного усилия, а масштабная инвариантность этой моды (кривые 1 и 4 на рис. 11, а) - диапазон пространственных частот (характерных масштабов), вовлеченных в пластические деформации. Наконец, воспроизводимость одной и той же азимутальной моды максимума ФАС разными видами геофизических полей (рис. 11) объясняется азимутально-направленным, стрессовым изменением объема горных пород (а значит, и всех их физических свойств) на единой территории в процессе самоподобной деформации ее частей. И если в отношении гравитационного поля подобное изменение объема очевидно и прямо ведет к изменению плотности, то изменение электрических и магнитных свойств горных пород при пластической деформации является опосредованным: для электропроводности - степенью открытости или закрытости микротрещин, концентрацией
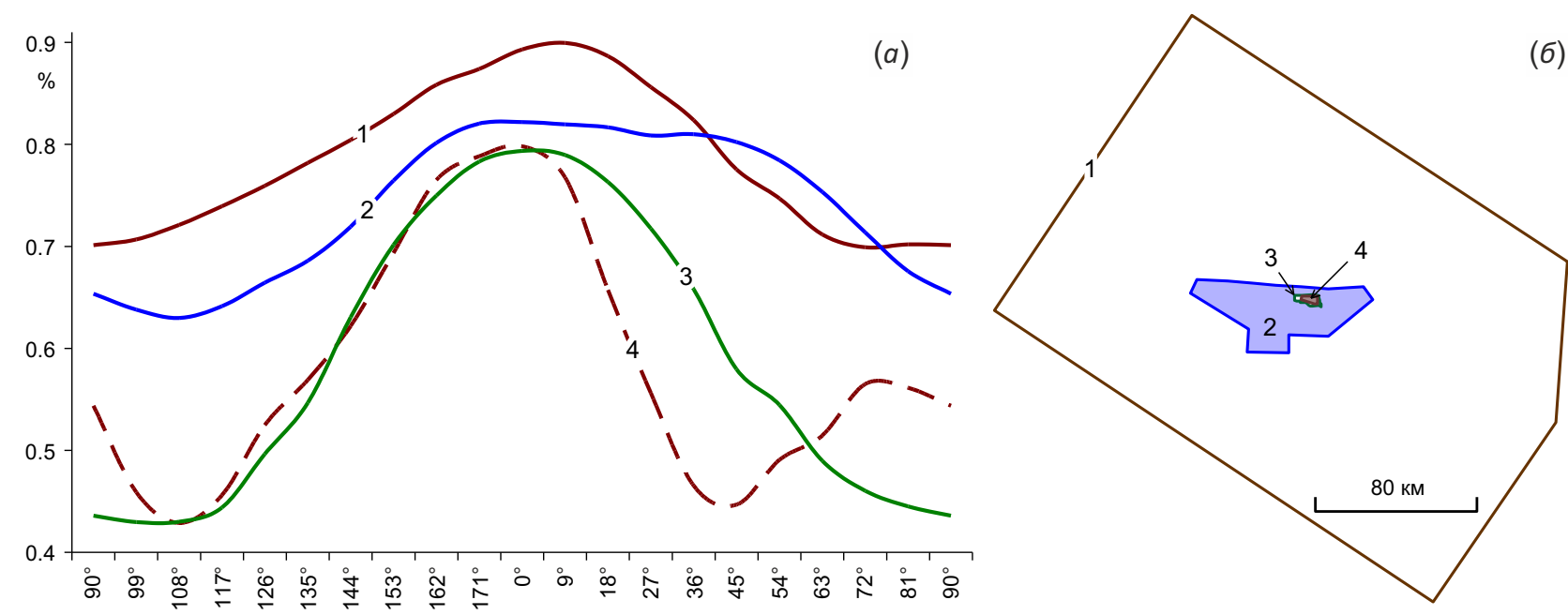

Рис. 11. Функция азимутального состояния разных геофизических полей на разных пространственных частотах (км-1) (a). Поля, измеренные с разной детальностью в пределах разных по размеру территорий (б): 1 - гравитационное в контуре большей части Алтае-Саянской складчатой области $\left(7 \mathrm{Km}^{-1}\right), 2$ - магнитное в контуре Ак-Сугского рудного узла $\left(1.2\right.$ км $\left.{ }^{-1}\right), 3-$ электрическое $\left(0.3 \mathrm{Kм}^{-1}\right), 4$ - гравитационное $\left(2.6 \mathrm{Km}^{-1}\right)$ в контуре Ак-Сугского меднопорфирового месторождения. Частные значения ФАС по оси ординат даны в процентах от суммарного значения на всех пространственных частотах.

Fig. 11. The function of the azimuthal state of different geophysical fields at different spatial frequencies $\left(\mathrm{km}^{-1}\right)(a)$. The fields were measured with different amount of detail within territories of different sizes (б): 1 - gravity field in the contour of most of the AltaiSayan folded area $\left(7 \mathrm{~km}^{-1}\right), 2$ - magnetic field in the contour of the Ak-Sug ore cluster $\left(1.2 \mathrm{~km}^{-1}\right), 3$ - electric field $\left(0.3 \mathrm{~km}{ }^{-1}\right)$ and $4-$ gravitational field $\left(2.6 \mathrm{~km}^{-1}\right)$ in the contour of the Ak-Sug porphyry copper deposit. Particular values of azimuthal state function along the ordinate axis are given as a percentage of the total value function at all spatial frequencies. 
и минерализацией пленочных вод в них [Krainov et al., 2004], для магнитной восприимчивости - содержанием магнетита, зависящим от концентрации кислорода в зонах относительно свободного или затрудненного проникновения воды по таким трещинам [Likhachev, 2017].

Сделанные с позиции деформационно-сдвигового концепта предположения еще недостаточны для полного объяснения рис. 10 и 11 (вопрос важен и ждет своего решения), но для объяснения этих же закономерностей с позиции блоково-интрузивного концепта интерпретации пришлось бы сделать менее правдоподобные предположения. Так, для объяснения рис. 10 и 11 необходимо допустить существование разномасштабных, но выдержанных по азимуту геологических объектов, имеющих одинаковое направление градиента изменчивости разных по своей физической природе свойств: плотности, электропроводности и магнитной восприимчивости.

Таким образом, при выборе наиболее правдоподобного концепта интерпретации геофизических полей следует рассматривать механические движения в недрах планеты прежде всего как процесс динамической самоорганизации единой на разных масштабных уровнях среды, обладающей фрактальным самоподобием своих частей. Игнорирование этого процесса (а скорее отсутствие методов его анализа) привело к сужению вопросов изучения геологической среды геофизическими методами до уровня эмпирики, которая не заметила губительного влияния статических моделей на мировоззрение, принятое геофизиками [Rodionov, 2006].

Тем не менее ни тот, ни другой из вышеназванных концептов интерпретации не является единственно правильным, но оба они должны рассматриваться совместно, как дополняющие друг друга до целого, как описывающие разные части формул физических свойств горных пород (блоково-интрузивный концепт - числитель, а деформационно-сдвиговый - знаменатель). В качестве примера взаимодополняющей интерпретации гравитационного поля с точки зрения двух разных концептов рассмотрим профиль гравитационного поля вдоль регионального геотраверса «Батолит», пересекшего западную границу Сибирской платформы через Енисейский кряж и Байкитскую антеклизу (рис. 12).

Из рис. 12 видно, что разные типы складчатости (продольная, больше характерная для складчатой области Енисейского кряжа, и поперечная, больше характерная для Сибирской платформы) отражаются в гравитационном поле зеркальным образом. Синформы складчатой области - Ангаро-Питский синклинорий и Приенисейский прогиб (насыщенный основными вулканитами и базит-ультрабазитовыми интрузиями) - отражаются положительными аномалиями гравитационного поля (положительными ветвями гравитационных

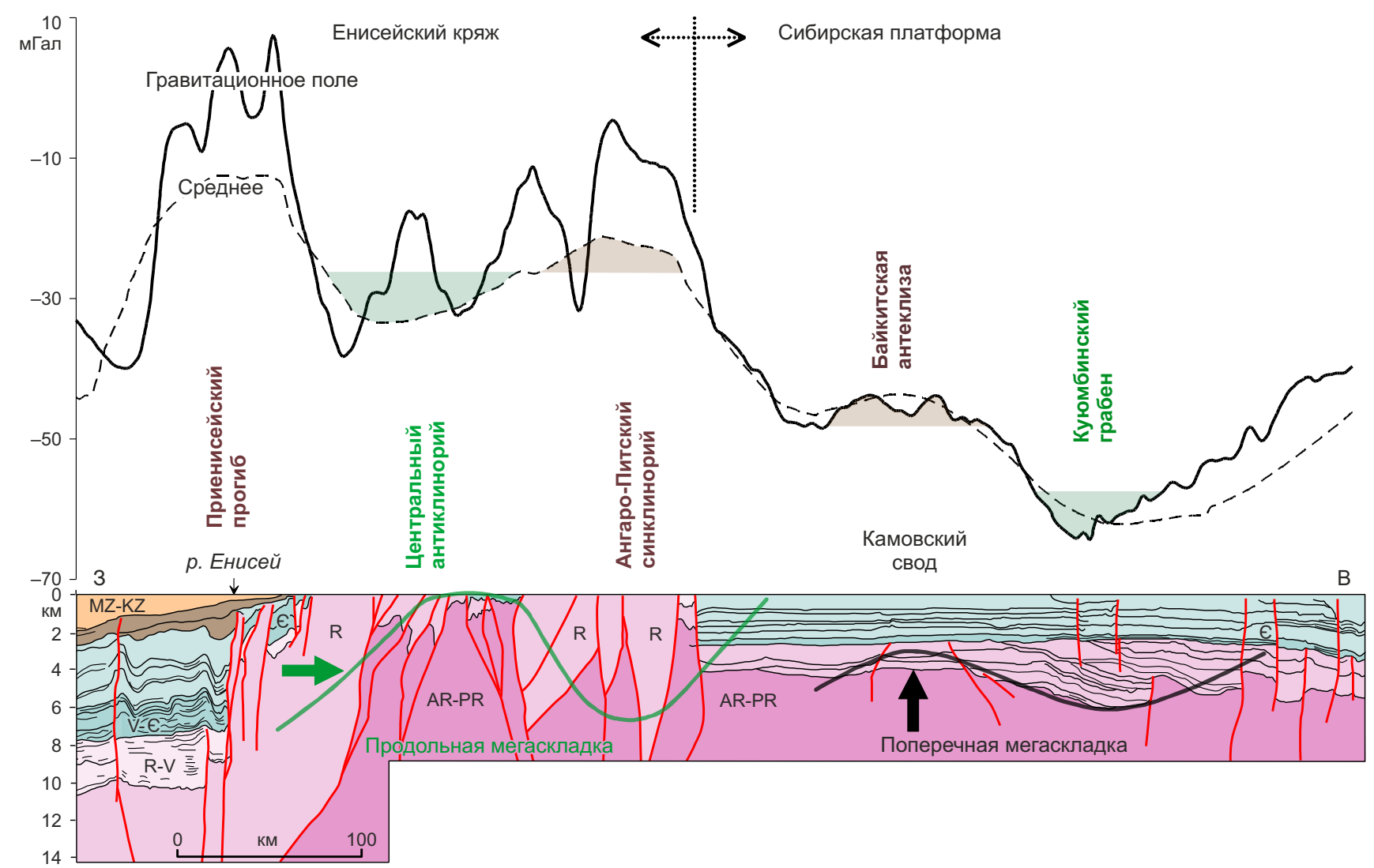

Рис. 12. Профиль гравитационного поля и геологический разрез вдоль геотраверса «Батолит» (по данным работы [Kheraskova et al., 2009]).

Fig. 12. Gravity field profile and geological section along the Batholith geotraverse (according to [Kheraskova et al., 2009]). 
дуплексов с точки зрения деформационно-сдвигового концепта), а синформы платформенных областей (Куюмбинский грабен с повышенной мощностью осадочных пород чехла) - отрицательными аномалиями. Для антиформ картина обратная: ключевые аномалеобразующие элементы, наполняющие антиформы складчатых областей, - гранитные плутоны - отражаются отрицательными аномалиями гравитационного поля (отрицательными ветвями гравитационных дуплексов с точки зрения деформационно-сдвигового концепта), а ключевые элементы антиформ платформенных областей - выступы гранитоидных пород фундамента (Камовский свод) - аномалиями положительного знака. Прямой перенос блоково-интрузивного концепта интерпретации с платформенной области на складчатую (или наоборот) привел бы к противоречию в геологической интерпретации гравитационных аномалий разного знака. Лишь дополнив традиционный блоково-интрузивный концепт интерпретации деформационно-сдвиговым (более соответствующим областям складчатости), можно не только избежать противоречий в геологической интерпретации данных гравиметрии, но и существенно ее дополнить. Вопервых, деформационно-сдвиговый концепт интерпретации региональных данных гравиметрии позволяет рассматривать совокупность основных и кислых интрузивов складчатых областей в виде положительных и отрицательных аномалий единых гравитационных дуплексов, отражающих строение сложных, но геологически единых объектов орогенеза - вулканоплутонических поясов, синформы которых обычно выполнены породами вулканического генезиса, а антиформы - плутонического. И, во-вторых, несмотря на зеркальную смену знаков аномалий гравитационных аномалий над син- и антиформами поперечной (платформенной) и продольной (орогенной) складчатости, транспрессивное взаимодействие между син- и антиформами этих двух видов складчатости проявляется в гравитационном поле одинаковым образом, а именно в виде наложенных на первичные гравитационные дуплексы вторичных деформационно-сдвиговых зон, для которых разнополярные аномалии, независимо от их природы, являются лишь носителями цепочек сдвигов, топологически конфигурированных между собой в межсдвиговые параллелограммы сжатия или растяжения (см. рис. 1, в, г). Это обстоятельство расширяет возможности корректного изучения геодинамики трансграничных территорий на стыке платформ и орогенов независимо от знака гравитационных аномалий над син- и антиформами поперечной и продольной складчатости.

\section{5. ЗАКЛЮЧЕНИЕ}

В заключение сформулируем наиболее важные, на наш взгляд, результаты гравиструктурного анализа, согласующиеся с выводами тектонофизического исследования, изложенными во введении. Первый из них установление направлений тектонического сжатия ЯАП: субмеридионального - $8^{\circ}$, субширотного - 98 ро-восточного - $38^{\circ}$ и северо-западного - $128^{\circ}$. Этот результат не противоречит выводу 2 тектонофизического исследования, но дополнительно позволяет однозначно установить кинематический знак сдвиговых движений, сопровождающих сжатие каждого из направлений, а также их относительную интенсивность (проявленность). Так, согласно рис. 4, ортогональные направления сжатия (правосдвиговые - $8^{\circ}$ и левосдвиговые - 98) проявлены статистически бо́льшим числом осей сжатия, чем диагональные (правосдвиговые $38^{\circ}$ и левосдвиговые $-128^{\circ}$ ).

Второй результат (не противоречащий выводу 3 тектонофизического исследования) заключается в том, что существенная роль в геодинамической эволюции ЯАП принадлежит субгоризонтальным деформациям кажущегося течения горных пород, установленным, в частности, вдоль границ Алакит-Оленекской минерагенической зоны (см. рис. 8).

Наконец, главный результат гравиструктурного анализа - выделение участков межсдвигового взаимодействия, контролирующих размещение кимберлитовых трубок и алмазоносных россыпей (см. рис. 7), - соответствует выводу 4 тектонофизического исследования, позволяя на регулярной основе распространить его на всю площадь ЯАП. Таким образом, следует полагать, что предложенный в настоящей статье гравиструктурный подход к интерпретации гравитационного поля можно отнести к упоминаемым в выводе 5 тектонофизического исследования геофизическим методам распознавания структур межсдвигового взаимодействия - к методам с весьма широкими перспективами не только регионального, но и локального прогноза кимберлитовых тел за счет переноса изложенной модели интерпретации на другие деформационно-чувствительные поля (электрические и магнитные) и масштабы исследования (см. рис 11).

\section{6. БЛАГОДАРНОСТИ}

Понимая дискуссионность и возможную преждевременность многих утверждений настоящей статьи, автор хотел бы выразить благодарность ее рецензентам за благожелательную критику, существенно улучшившую ее содержание, - в геофизической части А.С. Долгалю, в части геологической интерпретации П.А. Игнатову и Ф.В. Мясникову. Также автор выражает благодарность своему молодому коллеге - А.Е. Ануфриеву - за воплощение программного обеспечения частотно-азимутального анализа, существенно расширяющего возможности морфоструктурного изучения геофизических полей.

\section{7. ЛИТЕРАTУРA/ REFERENCES}

Bornyakov S.A., 1981. Tectonophysical Analysis of the Process of Formation of the Transform Zone in an ElasticViscous Model. In: N.A. Logachev, S.I. Sherman (Eds), Problems of Fault Tectonics. Nauka, Novosibirsk, p. 26-44 (in Russian) [Борняков C.A. Тектонофизический анализ процесса 
формирования трансформной зоны в упруговязкой модели // Проблемы разломной тектоники / Ред. Н.А. Логачев, С.И. Шерман. Новосибирск: Наука, 1981. С. 26-44].

Cowgill E., Yin A., Feng W.X., Qing Zh., 2000. Is the North Altyn Fault Part of a Strike-Slip Duplex along the Altyn Tagh Fault System? Geology 28 (3), 255-258. https://doi.org/10. 1130/0091-7613(2000)28<255:ITNAFP>2.0.CO;2.

Gladkov A.S., Bornyakov S.A., Manakov A.V., Matrosov V.A., 2008. Tectonophysical Studies for Diamond Prospecting. Guidelines. Nauchny Mir, Moscow, 175 p. (in Russian) [Гладков А.С., Борняков С.А., Манаков А.В., Матросов В.А. Тектонофизические исследования при алмазопоисковых работах: Методическое пособие. М.: Научный мир, 2008. 175 c.].

Gol'din S.V., 2002. Lithosphere Destruction and Physical Mesomechanics. Physical Mesomechanics 5 (5), 5-22 (in Russian) [Гольдин C.В. Деструкция литосферы и физическая мезомеханика // Физическая мезомеханика. 2002. T. 5. № 5. C. 5-22].

Ignatov P.A., Novikov K.V., Zaripov N.R., Khodnya M.S., Shmonov A.M., Razumov A.N., Kilizhekov O.K., Kovalchuk O.E., Kryazhev S.G., 2017. A Complex of Nontraditional Prospecting Indicators of Primary Diamond Deposits Used in Closed Areas. In: Problems of Minerageny, Economic Geology and Mineral Resources. Smirnov Collection-2017. MAKS Press, Moscow, p. 207-228 (in Russian) [Игнатов П.А., Новиков К.В., Зарипов Н.Р., Ходня М.С., Шмонов А.М., Разумов А.Н., Килижеков О.К., Ковальчук О.Е., Кряжев С.Г. Комплекс нетрадиционных поисковых признаков коренных месторождений алмазов, используемый на закрытых территориях // Проблемы минерагении, экономической геологии и минеральных ресурсов: Смирновский сборник-2017. М.: МАКС Пресс, 2017. С. 207-228].

Kheraskova T.N., Kaplan S.A., Galuev V.I., 2009. Structure of the Siberian Platform and Its Western Margin in the Riphean - Early Paleozoic. Geotectonics 43 (2), 37-56 (in Russian) [Хераскова Т.Н., Каплан С.А., Галуев В.И. Строение Сибирской платформы и ее западной окраины в рифее - раннем палеозое // Геотектоника. 2009. Т. 43. № 2. C. 37-56].

Krainov S.R., Ryzhenko B.N., Shvets V.M., 2004. Geochemistry of Groundwater. Theoretical, Applied and Environmental Aspects. Nauka, Moscow, 677 p. (in Russian) [Крайнов С.Р., Рыженко Б.Н., Швец В.М. Геохимия подземных вод. Теоретические, прикладные и экологические аспекты. М.: Наука, 2004. 677 с.].

Likhachev A.P., 2017. The Conditions of Magnetite and Its Ore Clusters Formation. Otechestvennaya Geologiya 4, 44-53 (in Russian) [Лихачев А.П. Условия образования магнетита и его рудных скоплений // Отечественная геология. 2017. № 4. С. 44-53].

Makarov P.V., 2007. Evolutionary Nature of Destruction of Solids and Media. Physical Mesomechanics 3 (10), 2338 (in Russian) [Макаров П.В. Эволюционная природа деструкции твердых тел и сред // Физическая мезомеханика. 2007. Т. 3. № 10. С. 23-38].

Makeev S.M., 2016. Solving of Two Problems of Geodynamics with the Gravity Structure Method. Geology and
Mineral Resources of Siberia 4, 63-74 (in Russian) [Макеев С.М. Решение двух задач геодинамики гравиструктурным методом // Геология и минерально-сырьевые ресурсы Сибири. 2016. № 4. С. 63-74].

Milashev V.A., 1979. The Structure of Kimberlite Fields. Nedra, Leningrad, 183 p. (in Russian) [Милашев B.А. Структуры кимберлитовых полей. Л.: Недра, 1979. 183 с.].

Molchanov Yu.D., Savrasov D.I., 1981. Physico-Geological Characteristics of Faults of the Vilyui-Markha Tectonic Zone within the Mirny Kimberlite Field. In: Geology, Diamond Content and Metallogeny of the Siberian Platform and Its Margins. IEC SB AN USSR, Irkutsk, p. 37-39 (in Russian) [Молчанов Ю.Д., Саврасов Д.И. Физико-геологическая характеристика разломов Вилюйско-Мархинской тектонической зоны в пределах Мирнинского кимберлитового поля // Геология, алмазоносность и металлогения Сибирской платформы и ее обрамления. Иркутск: ИЗК СО АН СССР, 1981. С. 37-39].

Nikolaevsky V.N., 2010. Geomechanics. Collection of Works. Vol. 1. Institute for Computer Research, Izhevsk, 640 p. (in Russian) [Николаевский В.Н. Геомеханика: Собрание трудов. Ижевск: Институт компьютерных исследований, 2010. Т. 1.640с.].

Odintsov M.M., 1957. Main Geological Features of the Siberian Diamond-Bearing Province. Bulletin of the Eastern Division of the USSR Academy of Sciences 1, 27-34 (in Russian) [Одинцов М.M. Основные черты геологии Сибирской алмазоносной провинции // Известия Восточного филиала АН СССР. 1957. № 1. С. 27-34].

Panin V.E., 1998. Foundations of Physical Mesomechanics. Physical Mesomechanics 1 (1), 5-22 (in Russian) [Панин В.Е. Основы физической мезомеханики // Физическая мезомеханика. 1998. Т. 1. № 1. С. 5-22].

Rodionov V.N., 2006. The Doctrine of Geomechanics. Geophysics 5, 61-64 (in Russian) [Родионов В.Н. Учение о геомеханике // Геофизика. 2006. № 5. С. 61-64].

Sadovsky M.A., 1979. Natural Lumpiness of Rocks. Doklady of the USSR Academy of Sciences 247 (4), 829-831 (in Russian] [Садовский М.A. Естественная кусковатость горной породы // Доклады АН СССР. 1979. Т. 247. № 4. C. 829-831].

Sarkarinejad K., Azizi A., 2008. Slip Partitioning and Inclined Dextral Transpression along the Zagros Thrust System, Iran. Journal of Structural Geology 30 (1), 116-136. http://dx.doi.org/10.1016/j.jsg.2007.10.001.

Seminsky K.Zh., 2003. Internal Structure of Continental Fault Zones. Tectonophysical Aspect. GEO, Novosibirsk, 244 p. (in Russian) [Семинский К.Ж. Внутренняя структура континентальных разломных зон. Тектонофизический аспект. Новосибирск: Гео, 2003. 244 с.].

Sherman S.I., Bornyakov S.A., Buddo V.Yu., 1983. Areas of Dynamic Influence of Faults (Modelling Results). Nauka, Novosibirsk, 112 p. (in Russian) [Шерман С.И., Борняков С.А., Буддо В.Ю. Области динамического влияния разломов (результаты моделирования). Новосибирск: Наука, 1983. 112 с.].

Sherman S.I., Seminsky K.Zh., Bornyakov S.A., Buddo V.Yu., Lobatskaya R.M., Adamovich A.N., Truskov V.A., Babichev A.A., 
1991. Faulting in the Lithosphere. Strike-Slip Zones. Vol. 1. Nauka, Novosibirsk, 261 p. (in Russian) [Шерман С.И., Cеминский К.Ж., Борняков С.А., Буддо В.Ю., Лобацкая Р.М., Адамович А.Н., Трусков В.А., Бабичев А.А. Разломообразование в литосфере. Зоны сдвига. Новосибирск: Наука, 1991. Т. 1. 261 с.].

Trushkov Yu.N. (Ed.), 1974. Structural Control of the Manifestations of Kimberlite Magmatism in the Northeast of the Siberian Platform. Nauka, Novosibirsk, 98 p. (in Russian) [Структурный контроль проявлений кимберлитового магматизма на северо-востоке Сибирской платформы / Ред. Ю.Н. Трушков. Новосибирск: Наука, 1974. 98 с.].
Twiss R.J., Moores E.M., 1992. Structural Geology. W.H. Freeman and Company, New York, 532 p.

Vaganov V.I., Golubev Yu.K., Minorin V.E., 2002. Evaluation of the Inferred Resources of Diamonds, Precious and Non-Ferrous Metals. Guidelines. Iss. "Diamonds". TSNIGRI, Moscow, 76 p. (in Russian) [Ваганов В.И., Голубев Ю.К., Минорин В.Е. Оценка прогнозных ресурсов алмазов, благородных и цветных металлов: Методическое руководство. М.: ЦНИГРИ, 2002. Вып. «Алмазы». 76 с.].

Woodcock N.H., Fischer M., 1986. Strike-Slip Duplexes. Journal of Structural Geology 8 (7), 725-735. http://dx. doi.org/10.1016/0191-8141(86)90021-0. 